\title{
Peningkatan Keterampilan Menulis Narasi melalui Media Gambar Seri Peserta Didik Kelas III Sekolah Dasar
}

\section{Isnaini Suci Rahayu}

Universitas Sebelas Maret

Isnainisucirahayu@gmail.com

\section{Article History}

received 30/4/2021

\begin{abstract}
One of the causes of low narrative writing skills is not using learning media optimally. The purpose of this study is to improve the skills of writing narratives using series image media. This study is a Classroom Action Research (CAR) with two cycles. The subject is the student class three of state Elementary School Ngoresan in academic year 2020/2021 with 28 students. The data collection techniques of this study used observation, interviews, documentation, and test. The initial condition of narrative writing skills of grade III students resuled in $32 \%$ classically, then after the action by applying serial image media to $61 \%$ in the first cycle, and increased to $86 \%$ in the second cycle. The conclusion in this study is that serial image media can improve narrative writing skills in third grade students of SDN Ngoresan the 2020/2021 academic year.
\end{abstract}

Keywords: Narrative text, writing skills, picture series

\section{Abstrak}

Salah satu penyebab rendahnya keterampilan menulis narasi adalah belum optimalnya penggunaan media pembelajaran. Tujuan dari penelitian ini adalah untuk meningkatkan keterampilan menulis narasi menggunakan media gambar seri. Penelitian ini merupakan Penelitian Tindakan Kelas (PTK) dengan dua siklus. Subyek penelitian adalah siswa kelas tiga SDN Ngoresan tahun pelajaran 2020/2021 dengan jumlah siswa 28 orang. Teknik pengumpulan data penelitian ini menggunakan observasi, wawancara, dokumentasi, dan tes awal. Kondisi keterampilan menulis narasi siswa kelas III secara klasikal diperoleh $32 \%$, kemudian setelah tindakan dengan menerapkan media gambar berseri menjadi $61 \%$ pada siklus I, dan meningkat menjadi $86 \%$ pada siklus II. Kesimpulan dalam penelitian ini adalah bahwa media gambar seri dapat meningkatkanmenulis narasi keterampilanpada siswa kelas III SDN Ngoresan yang 2020/2021 tahun akademik.

Kata kunci: Naratif teks, keterampilan menulis, media, gambar seri 


\section{PENDAHULUAN}

Pembelajaran Bahasa Indonesia memiliki peranan yang sangat penting, bukan hanya untuk membina keterampilan komunikasi melainkan juga untuk kepentingan penguasaan ilmu pengetahuan. Pembelajaran yang paling mendasar pada bahasa Indonesia di sekolah dasar adalah keterampilan menulis, karena hal tersebut merupakan dasar pelajaran bagi kelas selanjutnya. Keterampilan menulis adalah kemampuan mengungkapkan gagasan, pendapat, dan perasaan kepada pihak lain dengan melalui bahasa tulis (Mustikowati, 2016). Terdapat empat keterampilan berbahasa dalam bahasa Indonesia, antara lain: mendengarkan, berbicara, membaca, dan menulis (Dalman, 2018).

Menulis tidak hanya sekedar coretan tinta digoreskan didalam kertas, melaikan menulis wajib memiliki informasi serta maksud yang akan disampaikan kepada pembaca. Menulis ialah suatu proses menuangkan gagasan, ide, serta pemikiran ke dalam bentuk tulisan. Byrne dalam Slamet (2014) menyatakan bahwa keterampilan menulis tidak sekedar menulis simbol menjadi membentuk kalimat, tatapi keterampilan menulis ialah menuangkan pikiran menjadi kalimat disusun secara jelas serta utuh berupa tulisan, sehingga dapat dimengerti ke orang lain. Penulis harus terampil dalam mengaplikasikan kosakata serta struktur bahasa agar mudah dimengerti oleh pembaca. Menulis tidak hanya sekedar coretan tinta digoreskan didalam kertas, melaikan menulis wajib memiliki informasi serta maksud yang akan disampaikan kepada pembaca.

Pembelajaran keterampilan menulis narasi supaya semakin bermakna dapat dilakukan menggunakan media pembelajaran inovatif serta wajib sesuai dengan karakteristik peserta didik agar timbul minat yang tinggi terhadap pembalajaran bahasa Indonesia. Pembelajaran yang inovatif sangat diperlukan untuk memudahkan peserta didik dalam mengungkapkan ide serta pikiran dalam bentuk tulisan.

Berkaitan dengan hal tersebut, ditemukan data bahwa ada beberapa permasalahan yang menghambat keterampilan menulis pada peserta didik antara lain Peserta didik masih menggabungkan atau memadukan bahasa daerah dengan bahasa Indonesia saat menulis narasi. Selain itu peserta didik juga masih menggunakan pengulangan kosakata saat menulis cerita narasi. Peserta didik terkadang sulit untuk menulis kalimat utama dalam sebuah tulisan, dan juga mengalami kesulitan saat menuangkan pemikiran kedalam bentuk tulis. takata. Hasil keterampilan menulis narasi peserta didik dinilai masih rendah. Hal ini ditunjukkan dengan tingkat ketuntasan peserta didik yang hanya berjumlah 9 dari 19 atau sekitar $32 \%$, sedangkan $68 \%$ lainnya masih belum mampu mencapai KKM.

Redahnya keterampilan menulis narasi peserta didik perlu segera diatasi.Upaya untuk meningkatkan kemampuan peserta didik, guru harus mampu memberikan inovasi dalam pembelajaran untuk meningkatkan kualitas pembelajaran. Salah satu upaya guru dalam memingkatkan kualitas pembelajaran yaitu dengan menerapkan media pembelajaran yang menarik dan efektif. Media pembelajaran yang tepat untuk meningkatkan keterampilan menulis narasi peserta didik yaitu menggunakan media gambar seri. Media pembelajaran dapat menarik dan meningkatkan perhatian siswa sehingga siswa dapat lebih fokus terhadap materi pelajaran (Munadhi, 2010)

Menurut Subana (2011), penggunaan gambar seri sebagai media pembelajaran memiliki manfaat dapat menimbulkan daya tarik bagi siswa, mempermudah pemahaman siswa, memudahkan penjelasan yang sifatnya abstrak sehingga siswa lebih mudah memahami apa yang dimaksud, memperjelas bagian-bagian yang penting, dan menyingkat suatu uraian. Gambar seri adalah serangkaian gambar yang terpisah antara satu dengan lain tetapi mempunyai satu kesatuan urutan cerita (Madyawati, 2011). Dengan menggunakan gambar seri, peserta didik dilatih untuk mengungkapkan peristiwa dan 
kegiatan-kegiatan yang ada pada setiap gambar tersebut, sehingga akan menjadi suatu cerita yang saling berkaitan dan membentuk karangan yang utuh. Media gambar seri telah berhasil meningkatkan keterampilan menulis sederhana (Hasmira ,2018).

Berdasarkan pada beberapa hal yang sudah diuraikan di atas, maka tujuan penelitian ini yaitu untuk meningkatkan keterampilan menulis narasi dengan diterapkannya media gambar seri pada peserta didik kelas III SD Negeri Ngoresan tahun ajaran 2020/2021 Surakarta.

\section{METODE}

Penelitian yang diguankan ialah Penelitian Tindakan Kelas (PTK) dengan menerapkan model siklus. Penelitian Tindakan Kelas ialah proses pembahasan masalah pembelajaran di dalam kelas melalui refleksi, serta dilakukan berbagai Tindakan untuk memperbaiki masalah pembelajaran serta menganalisi setiap pengaruh tindakan tersebut (Sanjaya, 2013). Dalam PenelitianTindakan Kelas terdapat tindakan yang dilakukan untuk memperbaiki kualitas pembelajaran. Tindakan dilakukan secara berulang-ulang hingga tujuan penelitian tercapai. Penelitian dilakukan dua pertemuan pada masing-masing siklus. Subjek penelitian ini yaitu peserta didik kelas III SD Negeri Ngoresan Surakarta tahun ajaran 2020/2021 terdapat 28 peserta didik. Teknik pengumpulan data penelitian ini ialah pengamatan, wawancara, tes, serta dokumentasi. Uji validitas data menggunakan triangulasi sumber dan triangulasi teknik. Sementara itu, analisis data menggunakan model interaktif Miles-Huberman. Indikator kinerja pada penelitian ini yaitu $80 \%$ anak dapat mencapai Kriteria Ketuntasan Minimal (KKM) yang sudah ditentukan yakni sebesar $\geq 75$. Pada penelitian ini terdapat 5 kategori hasil keterampilan menulis narasi sebagai berikut :

Tabel 1. Kategori keterampilan menulis narasi

\begin{tabular}{cc}
\hline Interval Nilai & Kategori \\
\hline $87-100$ & Sangat Terampil \\
$75-86$ & Terampil \\
$62-74$ & Cukup Terampil \\
$49-61$ & Kurang terampil \\
$\leq 48$ & Tidak Terampil \\
\hline
\end{tabular}

HASIL DAN PEMBAHASAN

Hasil dari pratindakan membuktikan bahwa kondisi awal keterampilan menulis narasi peserta didik kelas III SD Negeri Ngoresan tergolong masih rendah. Hal tersebut berpengaruh terhadap skor rerata tiap aspek keterampilan menulis narsi. Untuk mengetahui skor rerata tiap aspek keterampilan menulis narasi pada pratindakan dapat dilihat pada tabel 2 di bawah ini.

Tabel 2. Skor Rerata Tiap Aspek Keterampilan Menulis Narasi pada Tes Pratindakan

\begin{tabular}{ccc}
\hline No. & Aspek yang dinilai & Skor Rerata \\
\hline 1. & Isi gagasan & 3,2 \\
2. & Kesesuaian isi dengan judul & 3,1 \\
3. & Diksi & 2,1 \\
4. & Penggunaan bahasa & 2,8 \\
5. & Mekanik & 2,3 \\
\hline
\end{tabular}


Berdasarkan dari Tabel 2 aspek isi gagasan memperoleh skor 3,2. Pada aspek kesesuaian isi dengan judul memperoleh skor 3,1. Pada aspek diksi memperoleh skor 2,1 . Pada aspek penggunaan bahasa memperoleh skor 2,8. Aspek mekanik memperoleh skor 2,3. Pada masing-masing aspek memiliki skor maksimal 4. Rerata nilai keterampilan menulis narasi pratindakan dipaparkan pada tabel 3 berikut.

Tabel 3. Nilai Keterampilan Menulis Narasi pada Pratindakan

\begin{tabular}{cccccc}
\hline No & Interval & $(\mathbf{f})$ & $\mathbf{( X i )}$ & $\mathbf{f . X i}$ & Persentase \% \\
\hline 1 & $45-51$ & 3 & 48 & 144 & 10,7 \\
2 & $52-58$ & 2 & 55 & 110 & 7,1 \\
3 & $59-65$ & 10 & 62 & 620 & 35,7 \\
4 & $66-72$ & 4 & 69 & 276 & 14,3 \\
5 & $73-79$ & 4 & 76 & 304 & 14,3 \\
6 & $80-87$ & 5 & 83 & 415 & 17,9 \\
Jumlah & 28 & & 1869 & 100 \\
Nilai Rerata & 67 & & & \\
Nilai Paling Tinggi & 85 & & & \\
Nilai Paling Rendah & 45 & & & \\
Nilai Diatas KKM & $9(32 \%)$ & & & \\
Tidak Tuntas & $19(68 \%)$ & & & \\
\hline
\end{tabular}

Berdasarkan dari Tabel 3 lebih banyak nilai dibawah KKM dibandingkan dengan yang sudah mencapai KKM. Terdapat 19 anak (68\%) belum tuntas, serta hanya 9 anak $(32 \%)$ yang tuntas mencapai KKM. Nilai tertinggi saat pratindakan adalah 85 serta nilai terendahnya 45, sedangkan nilai rerata kelas 67.

Setelah menerapkan media gambar seri saat pembelajaran materi menulis narasi. Nilai rerata keterampilan menulis narasi menunjukkan peningkatan pada siklus I jika dibandingkan dengan hasil tes pratindakan. Kareana pada siklus 1 belum mencapai indicator ketuntasan $80 \%$, maka dilanjutkan pada siklus II. Pada siklus II mengalami peningkatan dan telah mencapai indicator ketuntasan.

Berikut data perbandingan dari kondisi awal hingga akhir dipaparkan ke dalam Tabel 4 sebagai berikut:

Tabel 4. Perbandingan Nilai Keterampilan Menulis Narasi Pratindakan, Siklus I, Siklus II

\begin{tabular}{clccc}
\hline No & Keterangan & Pratindakan & Siklus I & Siklus II \\
\hline 1 & Nilai Terendah & 45 & 53 & 65 \\
2 & Nilai Tertinggi & 85 & 93 & 93 \\
3 & Nilai Rerata & 67 & 75,4 & 86 \\
& Ketuntasan & $(32 \%)$ & $(61 \%)$ & $(86 \%)$ \\
\hline
\end{tabular}

Berdasarkan dari Tabel 4 menunjukkan bahwa nilai terendah pada pratindakan sebesar 45 , kemudian meningkat menjadi 53 pada siklus I, selanjutnya pada siklus II menjadi 65. Perolehan nilai tertinggi pada pratindakan sebesar 85 , kemudian meningkat menjadi 93 pada siklus I dan siklus II. Rata-rata klasikal pada pratindakan 
67 , kemudian meningkat menjadi 75,4 pada siklus I, kemudian meningkat kembali menjadi 86 pada siklus II. Ketuntasan klasikal pada pratindakan sebesar $32 \%$, kemudian meningkat menjadi $61 \%$ pada siklus I, dan kembai meningkat menjadi $86 \%$ pada siklus II. Hal tersebut berpengaruh terhadap skor rerata tiap aspek keterampilan menulis narsi. Untuk mengetahui perbandingan skor rerata tiap aspek keterampilan menulis narasi dari kondisi awal hingga akhir dapat dilihat pada tabel 5 di bawah ini.

Tabel 5. Perbandingan Aspek yang Dinilai pada Keterampilan Menulis Narasi Pratindakan, Siklus I, Siklus II

\begin{tabular}{ccccc}
\hline No. & Aspek yang Dinilai & Pratindakan & Siklus I & Siklus II \\
\hline 1. & Isi Gagasan & 3,2 & 3,4 & 3,7 \\
2. & Kesesuaian Isi & 3,1 & 3,2 & 3,4 \\
3. & Diksi & 2,1 & 2,2 & 3 \\
4. & Penggunaan Bahasa & 2,8 & 3 & 3,4 \\
5. & Mekanik & 2,3 & 2,9 & 3,05 \\
\hline
\end{tabular}

Berdasarkan uraian Tabel 5 di atas, terlihat adanya peningkatan dalam setiap aspek. Aspek 1 yaitu aspek isi gagasan saat pratindakan memperoleh 3,2 kemudian siklus I bertambah menjadi 3,4 pada siklus II melonjak sebesar 3,7. Kemudian, Aspek 2 yaitu aspek kesesuaian isi saat pratindakan memperoleh 3,1 kemudian siklus I bertambah menjadi 3,2 keudian pada siklus II meningkat menjadi 3,4. Lalu, Aspek 3 ialah diksi saat pratindakan memperoleh 2,1, kemudian siklus I bertambah menjadi 2,2, siklus II meningkat menjadi 3. Selanjutnya Aspek 4 yaitu aspek penggunaan bahasa memiliki skor rerata 2,8 pada pratindakan, kemudian siklus I memperoleh skor 3 dan disiklus II melonjak sebesar 3,4. Terakhir adalah Aspek 5 yaitu aspek mekanik saat pratindakan memperoleh 2,3 kemudian pada siklus I meningkat menjadi 2,9 dan disiklus II melonjak sebesar 3,05.

Keterampilan menulis narasi anak kelas III SD Negeri Ngoresan Surakarta dinyatakan mengalami kenaikan melalui penerapan media gambar seri. Hal tersebut dibuktikan dari hasil tes tindakan yang dilakukan selalu memperlihatkan adanya peningkatan dengan persentase yang sudah dipaparkan sebelumnya. Peningkatan tersebut terjadi karena penerapan media gambar seri menjadikan proses pembelajaran menjadi lebih aktif, serta memudahkan peserta didik dalam gagasannya (Hasmira,2018). Penelitian ini diperkuat oleh penelitian yang relevan dari Ramadhan (2020) yeng memperlihatkan adanya peninkatan terhadap keterampilan menulis narasi melalui media gambar seri. Temuan lain tentang media gambar seri terdapat pada penelitian Risnawelli (2015) yang berhasil mengalami kenaikan keterampilan berbicara. Selain itu, penelitian oleh Naki (2018) berhasil mengalami kenaikan keterampilan menulis deskripsi. Berdasarkan uraian di atas, maka dapat diketahui bahwa media gambar seri dapat meningkatkan keterampilan menulis.

\section{SIMPULAN}

Berdasarkan dari hasil penelitian yang telah dilakukan pada dua siklus dengan menerapkan media gambar seri pada pembelajaran keterampilan menulis narasi pada peserta didik kelas III SD Negeri Ngoresan tahun ajaran 2020/2021 dapat disimpulkan bahwa penerapan media gambar seri dapat meningkatkan keterampilan menulis narasi pada peserta didik kelas III SD Negeri Ngoresan tahuan ajaran 2020/2021. Hal tersebut dibuktikan dengan adanya peningkatan dari hasil evaluasi pratindakan, siklus I, dan Siklus II. Ketuntasan klasikal pada Pratindakan sebesar (32\%). Ketuntasan klasikal meningkat pada siklus I sebesar (61\%). Ketuntasan klasikal 
pada siklus II meningkat menjadi (86\%). Sehigga indikator kinerja ketercapaian kinerja penelitian sebesar $80 \%$ dengan $\mathrm{KKM} \geq 75$ telah tercapai.

Peningkatan yang terjadi selama dua siklus dengan empat kali pertemuan dikarenakan peserta didik lebih mudah dalam menuliskan cerita dengan bantuan media gambar seri. Sehingga peserta didik memperoleh pengalaman dan pembelajaran yang bermakna. Berdasarkan penelitian yang telah dilaksanakan, salah satu media pembelajaran yang harus digunakan oleh guru dalam pelajaran Bahasa materi menulis narasi adalah media gambar seri. Melalui media gambar seri, peserta didik dilatih untuk menuangkan ide secara individu, secara jelas dan runtut.

\section{DAFTAR PUSTAKA}

H, Dalman. (2018). Keterampilan Menulis. Depok: Rajawali Press.

Hasmira. (2018). Meningkatkan Keterampilan Menulis Karangan Sederhana. PiJIES: Pedagogik Journal of Islamic Elementary School, 1(1), 47-56.

Madyawati , L. (2011). Modul Strategi Pengembangan Bahasa dan Cerita. Magelang: Universitas Muhammadiyah Magelang.

Munadhi , Y. (2010). Media Pembelajaran Sebuah Pendekatan Baru. Jakarta: Gaung Persada Press.

Mustikowati, D. (2016). Meningkatkan Semangat Membaca dan Menulis Siswa Sekolah Dasar dengan Permainan Kata Bersambut. Jurnal Riset dan Konseptual, $1(1)$, 39-42.

Naki, Nurhayati, \& Abidin. (2018). ANALISIS KEMAMPUAN MENULIS KARANGAN DESKRIPSI DALAM BAHASA INDONESIA MELALUI MEDIA GAMBAR SERI PADA SISWA KELAS VII SMP N 18 LAU KABUPATEN MAROS. Jurnal IImu Budaya, 6(2), 268-276.

Ramadhan, G. \& Dian. (2020). Peningkatan Keterampilan Menulis Teks Narasi NonFiksi melalui Media Gambar Seri. PEDADIDAKTIKA: JURNAL ILMIAH GURU SEKOLAH DASAR, 7(2), 178-188.

Risnawelli, N. (2015). Meningkatkan Keterampilan Berbicara Siswa dengan Media Gambar Seri. JPPI(Jurnal Penelitian Pendidikan Indonesia), 1(1), 27-35.

Sanjaya, W. (2013 ). Penelitian Tindakan Kelas . Jakarta: Kencana Prenada Media Group.

Slamet, S. Y. (2014). Pembelajaran Bahasa dan Sastra Indonesia di Kelas Rendah. Surakarta: UNS Press.

Subana \& Sunarti. (2011). Strategi Belajar Mengajar Bahasa Indonesia;Berbagai Pendekatan, Metode Teknik dan Media Pengajaran. Bandung: Pustaka Setia. 